\title{
COGNITIVE IMPAIRMENT DETECTION IN ADULT THALASSEMIA PATIENT USING MOCA-INA
}

\author{
Chandra Calista ${ }^{1}$, Uni Gamayani ${ }^{1}$, Anam ${ }^{1}$, Pandji Irani Fiaza ${ }^{2}$, Ahmad Rizal $^{1}$, Yusuf Wibisono ${ }^{1}$, Lisda Amalia ${ }^{1}$, Ramdan \\ Panigoro $^{3}$ \\ Correspondence: chandracalista@hotmail.com \\ ${ }^{l}$ Department of Neurology, Faculty of Medicine, Universitas Padjadjaran/Hasan Sadikin General Hospital, Indonesia \\ ${ }^{2}$ Department of Internal Medicine, Faculty of Medicine, Universitas Padjadjaran/Hasan Sadikin General Hospital, Indonesia \\ ${ }^{3}$ Department of Biomedical Science, Faculty of Medicine, Universitas Padjadjaran/ Hasan Sadikin General Hospital, RSP Unpad,, \\ Indonesia
}

\section{Article History:}

Received: April 12, 2020

Accepted: December 1, 2020

Published: January 1, 2020

\section{Cite this as:}

Calista C, Gamayani U, Anam A, Fiaza PI, Rizal A, Wibisono $Y$, Amalia L, Panigoro R. Cognitive impairment detection in adult thalassemia patient using mocaina. Malang Neurology Journal; 2021.7:24-29.

http://dx.doi.org/10.21776/ub.mnj .2021 .007 .01 .6

\section{ABSTRACT}

Background: Cognitive impairment in thalassemia patients are prevalent, therefore early detection of cognitive impairment in adult thalassemia patients is crucial for prevention. Montreal Cognitive Assessment (MoCA) is a public domain cognition screening tools that covers all cognitive domains in detecting mild cognitive impairments.

Objective: To compare cognitive function between adult thalassemia patients and healty control by using Indonesia version of MoCA test (MoCA-Ina)

Methods: This prospective observational analytic with case control study, compared the total scores and scores of each domain of cognition between adult thalassemia patients and healthy subjects at the Medical Hematology Oncology Clinic of Dr. Hasan Sadikin General Hospital, Bandung, Indonesia using MoCA-Ina from August to October 2018.

Results: A total of 32 thalassemia subjects and 50 healthy subjects were conducted. A total of $16(50 \%)$ subjects in the case group had a value of MoCA-Ina <26, while only $1(2 \%)$ healthy control had a value of MoCA-Ina <26. The median total MoCA-Ina score in case and control groups were 25.5 and $27.50(\mathrm{p}<0.001)$. The median score of memory domains, executive functions and visuospatial of the case and control groups were 3 versus 4 ( $p<0.001), 3$ versus 3.5 ( $p<0.001$ ) and $3.53 \pm 0.671$ versus $3.88 \pm 0.385$ ( $\mathrm{p}<0.003$ ), respectively.

Conclusion: Adults thalassemia patients have lower score in total MoCA-Ina, domains of memory, executive function and visuospatial score compared to healthy control.

Keywords: Cognitive function, MoCA-Ina, thalassemia

\section{Introduction}

One of the central neurologic complications in thalassemia patients is cognitive impairment. In most cases, these complications remains sub-clinic symptoms and were only detected in neurological examination and evaluation of neurological imaging.

Hypoxia due to anemia is the main factor that causes cognitive impairment. ${ }^{1,2}$ Iron deposition from an early age, especially in the area of the anterior pituitary gland, cortex, putamen and caudate nucleus results in brain damage that interferes with cognition. ${ }^{1,3}$ Hypercoagulability conditions cause easy occlusion of blood vessels resulting in infarction, in the cortical and subcortical regions, namely the putamen and caudate nucleus., ${ }^{2,3}$ Damage to the cortical and subcortical regions can cause cognitive impairment in thalassemia patients.

Montreal Cognitive Assessment (MoCA) is a global cognition function screening test developed to detect mild cognition disorders, predemetia stadium. MoCA has advantages as an instrument for detecting cognitive impairments because it covers all cognitive domains including executive function that were not assessed in Mini Mental State Examinations (MMSE) and superiorly in detecting mild cognitive impairment then MMSE and also can be done fast compared to other comprehensive neurocognitive test. ${ }^{4-7}$ MoCA has been validated and has been made the Indonesian version (MoCA-Ina). ${ }^{8}$

\section{Methods}

This was a prospective observational analitic case control study with consecutive sampling. conducted in the outpatient clinic of Medical Hematology Oncology Clinic of Dr. Hasan Sadikin General Hospital, Bandung, Indonesia during August to Oktober 2018. The protocol of the study was approved by the Institutional Ethics Committee. All human research procedures followed were in accordance with the ethical standards of the committee responsible for human experimentation (institutional and national), and with the Helsinki Declaration of 1975, as revised in 2013. Written informed consent was obtained prior to participation in the study

The inclusion criteria were patients above 18 years old, who have already been diagnosed with thalassemia 
undergone regular transfusion in the outpatient clinic of Medical Hematology Oncology Clinic of Dr. Hasan Sadikin General Hospital, Bandung. Control subjects were healthy population with matching age, gender and educational level, with normal hemoglobin level $(\mathrm{Hb})(>12 \mathrm{~g} / \mathrm{dL}$ for female and $>13 \mathrm{~g} / \mathrm{dL}$ for male $)^{9}$ and ferritin serum $(22-322$ $\mathrm{ng} / \mathrm{ml}$ for male and $10-291 \mathrm{ng} / \mathrm{ml}$ for female $)^{10,11}$.

Patients who had hearing disturbances, neurological deficits leading to suspicion of intracranial lesions, history of infectious diseases, head injuries, central nervous system infections, intracranial tumors, epilepsy, chronic health conditions, $^{12}$ liver or kidney disturbance based on information collected from medical report, questionnaire and routine neurological examination were excluded from this study.

All eligible subjects were consecutively approached as they came in for their regular transfusion schedule at the outpatient clinic of Medical Hematology Oncology Clinic during data collection period. Written informed consent was obtained prior to participation in the study. At the beginning of the examination and interview, all respondents were informed of the objectives of the study and were assured that all responses would be kept confidential.

All subject undergo cognitive evaluation using MoCA-Ina. The MoCA-Ina value of the case group will be compared with references obtained from the control group in this study. We also obtain data such as education level, hemoglobin level, ferritin level, and body mass index (BMI) in both groups. This variables were known have differences between two groups. ${ }^{13-15}$

Data analysis was performed using IBM $®$ SPSS $®$ Statistics version 23.0 program. Results were expressed in mean \pm standard deviation and median for quantitative variables and in number and percentage for qualitative ones. The MoCA-Ina score between the two groups were compared.

\section{Results}

Tabel 1. Demographic data of thalassemia patients and controls

\begin{tabular}{|c|c|c|c|}
\hline \multirow[b]{2}{*}{ Variable } & \multicolumn{2}{|c|}{ Groups } & \multirow[b]{2}{*}{ p-value } \\
\hline & $\begin{array}{c}\text { Thalassemia } \\
\quad(n=32)\end{array}$ & $\begin{array}{c}\text { Controls } \\
(\mathbf{n}=50)\end{array}$ & \\
\hline Sex & & & 0.821 \\
\hline Male & $12(37.50 \%)$ & $20(40.00 \%)$ & \\
\hline Female & $20(62.50 \%)$ & $30(60.00 \%)$ & \\
\hline Age (years) & & & 0.456 \\
\hline Median & 23,60 & 23,79 & \\
\hline Range (min-max) & $18,33-36,76$ & $19,20-37,57$ & \\
\hline $\begin{array}{l}\text { Education level } \\
\text { (years) }\end{array}$ & & & 0.649 \\
\hline Median & 12.00 & 10.50 & \\
\hline Range (min-max) & $6.00-16.00$ & $6.00-16.00$ & \\
\hline $\begin{array}{l}\text { Hemoglobin } \\
(\mathrm{mg} / \mathrm{dl})\end{array}$ & & & $<0.001 * *$ \\
\hline Mean \pm SD & $6.98 \pm 0.84$ & $14.38 \pm 1.50$ & \\
\hline Ferritin (ng/dl) & & & $<0.001 * *$ \\
\hline Median & 2561 & 46.35 & \\
\hline Range (min-max) & $253-11000$ & $11-322$ & \\
\hline BMI & & & $<0.001 * *$ \\
\hline Mean \pm SD & $18.28 \pm 2.28$ & $22.66 \pm 4.089$ & \\
\hline
\end{tabular}

During August to Oktober 2018 there were 32 adults thalassemia subjects and 50 healthy subject were obtained. Tabel 1 showed the characteristic and the statistic analysis for both groups. There were $20(62.50 \%)$ female subjects with median 23.6 years old and median of education level were 12 years in case group. On the other hand, controlled groups consist of $30(60 \%)$ female, with median age 23.79 years old and median of education level 10.50 years.

Tabel 2. MoCA-Ina score comparison between Thalassemia patients and controls

\begin{tabular}{|c|c|c|c|}
\hline \multirow[b]{2}{*}{ Variable } & \multicolumn{2}{|c|}{ Groups } & \multirow[b]{2}{*}{ p-value } \\
\hline & $\begin{array}{c}\text { Thalassemia } \\
\quad(n=32)\end{array}$ & $\begin{array}{c}\text { Controls } \\
(n=50)\end{array}$ & \\
\hline \multicolumn{4}{|l|}{ MoCA-Ina score } \\
\hline$<26$ & $16(50.00 \%)$ & $1(2.00 \%)$ & $<0.001 * *$ \\
\hline$\geq 26$ & $16(50.00 \%)$ & $49(98 \%)$ & \\
\hline Range (min-max) & $0,00-5,00$ & $2,00-5,00$ & \\
\hline Total MoCA-Ina & & & $<0.001 * *$ \\
\hline Median & 25.50 & 27.50 & \\
\hline Range (min-max) & $16.00-29.00$ & $25.00-30.00$ & \\
\hline Domain Atensi & & & 0.099 \\
\hline Mean \pm Std & $4.71 \pm 1.224$ & $5.20 \pm 0.832$ & \\
\hline Median & 5.00 & 5.00 & \\
\hline Range (min-max) & $2.00-6.00$ & $3.00-6.00$ & \\
\hline Orientation Domain & & & 0.130 \\
\hline Mean \pm Std & $5.87 \pm 0.421$ & $5.98 \pm 0.141$ & \\
\hline Median & 6.00 & 6.00 & \\
\hline Range (min-max) & $4.00-6.00$ & $5.00-6.00$ & \\
\hline Domain Language & & & 0.692 \\
\hline Mean \pm Std & $4.75 \pm 0.567$ & $4.76 \pm 0.431$ & \\
\hline Median & 5.00 & 5.00 & \\
\hline Range (min-max) & $3.00-5.00$ & $4.00-5.00$ & \\
\hline Memory Domain & & & $<0.001 * *$ \\
\hline Mean \pm Std & $2.87 \pm 1.313$ & $3.98 \pm 1.020$ & \\
\hline Median & 3.00 & 4.00 & \\
\hline Range (min-max) & $0.00-5.00$ & $2.00-5.00$ & \\
\hline Domain Visuospatial & & & $<0.003 *$ \\
\hline Mean \pm Std & $3.53 \pm 0.671$ & $3.88 \pm 0.385$ & \\
\hline Median & 4,00 & 4,00 & \\
\hline Range (min-max) & $2.00-4.00$ & $2.00-4.00$ & \\
\hline Executive Function & & & $<0.001 * *$ \\
\hline Mean \pm Std & $2.68 \pm 0.931$ & $3.36 \pm 0.749$ & \\
\hline Median & 3.00 & 3.50 & \\
\hline Range (min-max) & $1.00-4.00$ & $1.00-4.00$ & \\
\hline
\end{tabular}

Results of MoCA-Ina examination from both groups showed in tabel 2. We Obtained a statistically significant difference $(p<0,05)$ in total MoCA-Ina, domains of memory, executive function and visuospatial score between both groups. $16(50 \%)$ subjects in case group has MoCAIna score less than 26, while only $1(2 \%)$ subject in control group who has MoCA-Ina score less than 26 ( $\mathrm{p}<0,001 * * *)$. Case groups has median of total MoCA-Ina 25.50 with details median domains of attention 5.00, language 5.00, memory 3.00 , orientation 6.00 , visuospatial 4.00 , and executive function 3.00. Controlled groups has total MoCA-Ina score 27.50, with details median domains of memory 4.00 , orientation 6.00 , visuospatial 4.00 , language 5.00 while mean of attention were 5.00 and executive function were 3.50 .

Tabel 3 showed corelation between hemoglobine, hematocrite $(\mathrm{Ht})$, ferritin and Body Mass Index (BMI) to total MoCA-Ina score and each domains ( $\mathrm{p}<0.05)$. Hemoglobin level and hematocrite has positive correlation 
Table 3. Factors affect cognitive in thalassemia patients

\begin{tabular}{|c|c|c|c|c|c|c|c|c|}
\hline \multirow{2}{*}{ Variable } & \multicolumn{2}{|c|}{ Hemoglobin } & \multicolumn{2}{|c|}{ Hematocrite } & \multicolumn{2}{|c|}{ Ferritin } & \multicolumn{2}{|c|}{ BMI } \\
\hline & $\mathbf{r}$ & p-value & $\mathbf{r}$ & p-value & $\mathbf{r}$ & p-value & $\mathbf{r}$ & p-value \\
\hline Total MoCA-Ina & $0,421^{* * *}$ & $<0,001$ & $0,458^{* *}$ & $<0,001$ & $-0,314^{* *}$ & 0,004 & $0,352^{* * *}$ & 0,001 \\
\hline Memory domain & $0,368^{* *}$ & 0,001 & $0,417^{* *}$ & $<0,001$ & $-0,271^{*}$ & 0,014 & $0,342^{* *}$ & 0,002 \\
\hline Orientation domain & 0,123 & 0,271 & 0,198 & 0,075 & $-0,180$ & 0,107 & $0,253^{*}$ & 0,022 \\
\hline Executive function domain & $0,297^{* *}$ & 0,007 & $0,323^{* *}$ & 0,003 & $-0,312^{* *}$ & 0,004 & $0,224^{*}$ & 0,043 \\
\hline Visuospatial domain & $0,321^{* *}$ & 0,003 & $0,291^{* *}$ & 0,008 & $-0,235^{*}$ & 0,033 & $0,242^{*}$ & 0,028 \\
\hline Atenttion domain & 0,161 & 0,148 & 0,193 & 0,082 & $-0,160$ & 0,150 & 0,187 & 0,093 \\
\hline Language domain & $-0,142$ & 0,204 & $-0,133$ & 0,234 & $-0,010$ & 0,927 & 0,033 & 0,766 \\
\hline
\end{tabular}

to total MoCA-Ina score ( $r=0.421$ and 0.458$)$, while ferritin has negative correlation $(\mathrm{r}=-0,314)$. BMI also has positive correlation $(\mathrm{r}=0.352)$.

The correlation between memory and hemoglobin, hematocite, ferritin and BMI were $\mathrm{r}=0.368,0.472,-0.271$, 0.342 , respectively. Visuospatial has also correlation with hemoglobin, hematocrite, ferritin and BMI ( $r=0.321,0.291$, -0.235 and 0.242 ). Orientation has positive correlation with BMI ( $r=0.253)$. Executive function has low correlation with hemoglobin, hematocrite, ferritin and BMI ( $\mathrm{r}=0.297$, $0.323,-0.321,0.224)$.

\section{Discussion}

Most of the subjects were females due to the sampling technique were consecutive sampling. Study by Maatook et all and Trehan et all showed there were no discrepancy in gender of thelessemia patients. Both male and female obtain their gene inheritance by dominant autosomal inheritance. $^{16-18}$

The median age for this study were 23.60 years old. Elhaniny et all who obtain subjects 18 years and above, showed that the mean age for major thalassemia patients was $25.05 \pm 2.61$ years old and intermedia thalassemia was $31.15 \pm 9.77$ years old. ${ }^{19}$ Life expectancy of thalassemia patiens has greatly increased in line with the development of medical science, especially with the usage of iron chelator agents. Iron chelator agents have reduce mortality from 6 times to 2.8 times. Before regular use of iron chelator agents, thalassemia patients who undergo regular blood tranfusion died in their teens due to iron deposition in the heart. ${ }^{16,20-23}$ Study in Iran in 2015 showed the median age of thalassemia patients were 20 years with the range 0.97-56.6 years and the life expectancy thalassemia patients in their 10-, 20-, and 30- years were 98.3\%, 88.4\% and $80.5 \%{ }^{24}$

The median levels of education on subjects were 12 years. Study in North America showed that 60\% thalassemia patients had education up to college and $14 \%$ had their doctoral degree. ${ }^{25}$ Study in Cairo in 2016 showed mean education level of major thalassemia and intermedia thalassemia patients were $6.3 \pm 3.50$ years and $7.90 \pm 3.5$ years. Various factors influence their education levels, such as the frequency of blood transfusion which makes patients go back and forth to the hospital, obedience to take take the iron chelator medication, self-respect, family support, and their opportunity to go to school. Patients usually have physical complaints as a result from their anemia that leads to disturbance of their performance in school. ${ }^{26,27}$
Mean BMI of case group were $18.28 \pm 2.28 \mathrm{~kg}$, which statistically significant compared to control group. There were positive correlation between IMT and total MoCA-Ina score, memory domain, orientation domain, executive function and visuospatial domain. This is due to endocrine dysfunction caused by iron deposition. Endocrine disturbance manifest as disruption of growth hormone $(\mathrm{GH})$ production that leads to interference of growth and development. Hypogonadism, hypothyroid, and disturbance of GH to insuline-like growth factor-1 (IGF-1) as a result of hemosiderosis in pituitary and liver also plays a role in growth disturbance of thalassemia patients. ${ }^{18,28-30}$

One of the factors which plays a role in ormal growth of major thalassemia children for the first 10 years was their hemoglobin levels. If a child has hemoglobin less that $8.5 \mathrm{~g} / \mathrm{dl}$, it can leads them to hypoxia condition which becomes main factor of stunted growth. Maintaining hemoglobin levels above $10-11 \mathrm{~g} / \mathrm{dl}$ followed by a proper iron chelator makes major thalassemia patients appears normal dan difficults to distinguish from their peers. Growth delay starting to appears by the age of 10 , eventough adequate hemoglobin levels were maintained. Shalitin et all proposed the mean ferritin of $2500 \mathrm{ng} / \mathrm{ml}$ during puberty was the cut-off point for hipogonadism, and ferritin levels of $3000 \mathrm{ng} / \mathrm{ml}$ during pre-puberty was the cutoff points of short stature. Gomber and Dewan revealed thatif ferritin increased more than $300 \mathrm{ng} / \mathrm{ml}$ then growth disturbance becomes obvious. $^{29,31}$

Table 2 showed in general MOCA-Ina score of case group lower compared to control, except for atenttion, orientation, and language. This result suitable with previous stuby by Monastero in 2000, which stated that there was cognitive impairement in adult thalassemia patients. Affected domains were atettion, memory, visuospatial and executive function. ${ }^{32}$ Lestari in 2016 concluded that working memory of major beta thalassemia child patient affects towards their school performance and quality of life. ${ }^{33}$ Rafaat et all also showed that there was memory disturbance in thalassemia patients. $^{34}$

Anemia leads disturbance in cognitive by volume changes of basal ganglia and thalamus, associated with lower IQ and memory disturbance Lin $^{35,36}$ et all showed that acute isovolemic anemial leads to visuospatial disturbance, working memory and learning disorder, which has been shown in mice model that had hipoxia responce escalation due to anemia. ${ }^{37}$

High ferritin levels showed iron deposition in body. This iron deposition not only occurred in systemic, but also in brain as hemosiderosis was found in pituitary. Interistingly, 
study by Akhlaghpoor et all reveals that thalassemia patients had significantly lower T2* values in basal ganglia (striatum), thalamus and adenohypophysis compared to controls while there were no differences in the midbrain (red nucleus). ${ }^{38}$ Study by Lam et all showed that ferritin was found to be associated with T2SI (signal intensity) pituitary and T2 pituitary, and also there was significant correlation of T2SI pituitary with IGF-1 and insulin-like growth factor binding protein-3 (IGFBP-3). ${ }^{39}$

Iron disturbance in adenohypophysis will affect $\mathrm{GH}$ and IGF-1. ${ }^{18,28-30} \mathrm{GH}$ affects the work of limbic and hypothalamus. ${ }^{40,41}$ Spesific reseptors of GH scattered on brain including area related to long-term potentiation (LTP). LTP between two neurons were important components in synaptic plasticity which related with longterm memory (LTM) storage in cellular levels. ${ }^{42,43}$ LTP has not detected yet in all parts of brain, but it is clearly found in prefrontal cortex, hypocampus, and amigdala which related to cognitive. ${ }^{44}$

Table 3 showed positive correlation between BMI and MoCA-Ina score. Thalassemia patients had lower BMI due to many factors such as growth hormone deficiency, hypothyroidism, hypogonadism, low $\mathrm{Hb}$ levels, bone disorders and desferrioxamine toxicity. ${ }^{45,46}$

This result corresponds to prior study by Estrella-Castillo et all that showed subjects with lower weight have poorer cognitive compared to normal population. ${ }^{47}$ Study by Joo et all concluded that subjects that have lower BMI has progressive risk to have Alzheimer's compared to normal ${ }^{13}$ while Suemoto et all showed that decrease BMI leads to decreased of memory function within 12 years. ${ }^{48}$

Poor nutritional status can leads to decreased leptin production, lack of vitamin, essential fat and can caused oxidative damage on neuron cells and accelerate degenerative proses of nerve cells. ${ }^{13,48}$ Lower leptin serum was found on Alzheimer's patients with BMI less than 20 compared in patients with BMI > 25. Temporal mesial cortex degeneration which include limbic that plays a role in appetite, eating habit, memory and emotional regulation, all of them can affect weight. ${ }^{13}$

\section{Conclusion}

Compared to normal subject, thalassemia has cognitive impairment using MoCa-Ina. Hemoglobin and hematocrite has positive correlation to MoCA-Ina score while ferritin has negative correlation.

\section{Acknowledgement}

We would like to extend our gratitude to all the staff and management of Hematology Oncology Medic Clinic and Memory Clinic of Dr. Hasan Sadikin General Hospital, Bandung, Indonesia for their encouragement and support throughout the study.

\section{References}

1. Zafeiriou DI, Economou M, Athanasiou-Metaxa M. Neurological complications in $\beta$-thalassemia. Brain Dev; 2006. 28(8):477-81.

DOI: 10.1016/j.braindev.2006.02.005
2. Eldor A, Rachmilewitz EA. The hypercoagulable state in thalassemia. Blood; 2002. 99(1):36-43. DOI: $10.3109 / 03630260903351619$

3. Argyropoulou MI, Astrakas L. MRI evaluation of tissue iron burden in patients with $\beta$-thalassaemia major. Pediatr Radiol; 2007. 37(12):1191-200.

DOI: $10.1007 / \mathrm{s} 00247-007-0567-1$

4. Elliott EN, Kaestner KH. The Montreal Cognitive Assessment (MoCA): Creating a crosswalk with the Mini-Mental State Examination. J Geriatr Psychiatry Neurol; $2016 . \quad 72(21): 4139-56$. DOI:10.1111/jgs. 13710

5. Trzepacz PT, Hochstetler H, Wang S, Walker B, Saykin AJ. Relationship between the Montreal Cognitive Assessment and Mini-mental State Examination for assessment of mild cognitive impairment in older adults. BMC Geriatr; 2015. 15(1):1-9. DOI: 10.1186/s12877-015-0103-3

6. Santangelo G, Siciliano M, Pedone R, Vitale C, Falco F, Bisogno R, et al. Normative data for the Montreal Cognitive Assessment in an Italian population sample. Neurol Sci; 2015.36(4).

DOI: 10.1007/s10072-014-1995-y

7. Borland E, Nägga K, Nilsson PM, Minthon L, Nilsson ED, Palmqvist S. The Montreal Cognitive Assessment: Normative data from a Large Swedish Population-Based Cohort. J Alzheimer's Dis; 2017. 59(3):893-901. DOI: 10.3233/JAD-170203

8. Husein N, Lumempouw S, Ramli Y, Herqutanto. Montreal Cognitive Assessment versi Indonesia (MoCA-Ina) untuk skrining gangguan fungsi kognitif. Neurona; 2010. 27(4). Available from: http://www.neurona.web.id/paper-detail.do?id=734

9. World Health Organization. Haemoglobin concentrations for the diagnosis of anaemia and assessment of severity [Internet]. Vitamin and Mineral Nutrition Information System. Geneva: World Health Organization; 2011. p. 1-6. Available from:

https://www.who.int/vmnis/indicators/haemoglobin/ en/

10. Gracia-Casal MN, Sant-Rayn P, Martinez RX, Lopez-Perez L, Peña-rosas JP. Serum or plasma ferritin concentration as an index of iron deficiency and overload (Protocol). Cochrane Database Syst Rev; 2015. (7). DOI: 10.1002/14651858.CD011817

11. World Health Organization. Serum ferritin concentrations for the assessment of iron status and iron deficiency in populations. World Health Organization. Geneva; 2011. p. 1-5. Available from: https://www.who.int/vmnis/indicators/serum_ferritin .pdf

12. Bernell S, Howard SW. Use Your Words Carefully: What Is a Chronic Disease? Front Public Heal; 2016. 4(August):2-4. DOI: 10.3389/fpubh.2016.00159

13. Joo SH, Yun SH, Kang DW, Hahn CT, Lim HK, Lee CU. Body mass index in mild cognitive impairment according to age, sex, cognitive intervention, and hypertension and risk of progression to Alzheimer's disease. Front Psychiatry; 2018. 9(Apr):1-8.

DOI: $10.3389 /$ fpsyt.2018.00142 
14. Sungthong R, Mo-suwan L, Chongsuvivatwong V. Effects of haemoglobin and serum ferritin on cognitive function in school children. Asia Pac J Clin Nutr; 2002.11(2):117-22. DOI: 10.1046/j.14406047.2002.00272.x

15. Lambert A, Knaggs K, Scragg R, Metcalf P, Schaaf D. Effects of iron treatment on cognitive performance and working memory in non-anaemic , iron-deficient girls. NZ J Psychol; 2002. 31(1):19$28 . \quad$ Available from: https://www.researchgate.net/publication/283380250 _Effects_of_iron_treatment_on_cognitive_performa nce_and_working_memory_in_non-anaemic_irondeficient_girls

16. Maatook MA, Mohammed KA, Afat AM. The socio-demographic profile of thalassemia in Basrah. Med J Babylon; 2015.12(3):670-6.

DOI: $10.21474 / \mathrm{IJAR} 01 / 7465$

17. Trehan A, Sharma N, Das R, Bansal D, Marwaha RK. Clinicoinvestigational and demographic profile of children with thalassemia major. Indian $\mathbf{J}$ Hematol Blood Tranfus; 2015. 31(1):121-6. DOI: $10.1007 / \mathrm{s} 12288-014-0388-\mathrm{y}$

18. Olivieri NF. The $\beta$ - Thalassemias. N Engl J Med; 2014.341(2):99-109.

DOI: $10.1056 /$ NEJM199907083410207

19. Elhabiby MM, ElSalakawy W, Khalil SA, Hassan DI, Hjislam SG. Cognitive dysfunction in $\beta$ thalassemia major and intermedia patients and its clinical correlates. Middle East Curr Psychiatry; 2016.23(3):128-33.

DOI: 10.1097/01.XME.0000484344.49943.1c

20. Amoudi AS, Balkhoyor AH, Abulaban AA, Azab AM, Radi SA, Ayoub MD, et al. Quality of life among adults with beta-thalassemia major in western Saudi Arabia. Saudi Med J; 2014. 35(8):882-5. Available from: https://pubmed.ncbi.nlm.nih.gov/25129193/

21. Vitrano A, Calvaruso G, Lai E, Colletta G, Quota A, Gerardi C, et al. The era of comparable life expectancy between thalassaemia major and intermedia: Is it time to revisit the major-intermedia dichotomy? $\mathrm{Br} \mathrm{J}$ Haematol; 2017. 176(October 2016):124-30. DOI: 10.1111/bjh.14381

22. Pakbaz Z, Treadwell M, Yamashita R, Quirolo K, Foote D, Quill L, et al. Quality of life in patients with thalassemia intermedia compared to thalassemia major. Ann N Y Acad Sci; 2005. 1054:457-61. DOI: 10.1196/annals.1345.059

23. Poggiali E, Cassinerio E, Zanaboni L, Cappellini MD. An update on iron chelation therapy. Blood Transfus; 2012.10:411-22. DOI 10.2450/2012.000812

24. Zamani R, Khazaei S. Survival Analysis and its Associated Factors of Beta Thalassemia Major in Hamadan Province. Iran J Med Sci; 2015. 40(3):233-9. Available from: https://www.ncbi.nlm.nih.gov/pmc/articles/PMC443 0885/

25. Pakbaz Z, Treadwell M, Kim H-Y, Trachtenberg F, Parmar N, Kwiatkowski JL, et al. Education and employment status of children and adults with thalassemia in North America. Pediatr Blood Cancer; 2015.85(0 1):1-27.

DOI: $10.1002 /$ pbc. 22565

26. Wijaya LJ, Nency YM, Farida H. Faktor-faktor utama yang mempengaruhi prestasi belajar pasien talasemia mayor anak. J Kedokt Diponegoro; 2018.7(2):694-710. Available from: https://ejournal3.undip.ac.id/index.php/medico/articl e/view/20719

27. Aji DN, Silman C, Aryudi C, Andalia D, Astari D, Pitaloka DD, et al. Faktor-faktor yang berhubungan dengan kualitas hidup pasien thalassemia mayor di pusat thalassemia departemen ilmu kesehatan anak RSCM. Sari Pediatr; 2009.11(2):85-9. Available from: $\quad$ https://saripediatri.org/index.php/saripediatri/article/view/598

28. Shalitin S, Carmi D, Weintrob N, Phillip M, Miskin $\mathrm{H}$, Kornreich L, et al. Serum ferritin level as a predictor of impaired growth and puberty in thalassemia major patients. Eur J Haematol; 2005. 74(2):93-100. DOI: $\quad$ 10.1111/j.16000609.2004.00371.x

29. Karamifar H, Shahriari M, Amirhakimi G. Linear growth deficiency in $\beta$-thalassemia patients: Is it growth hormone dependent? Iran J Med Sci; 2002.27(2):47-50. Available from: https://ijms.sums.ac.ir/article_40243.html

30. Prakash A, Aggarwal R. Thalassemia major in adults: Short stature, hyperpigmentation, inadequate chelation, and transfusion-transmitted infections are key features. N Am J Med Sci; 2012.4(3):141-4. DOI: $10.4103 / 1947-2714.93886$

31. Arimbawa M, Ketut A. Profil Pertumbuhan, hemoglobin pre-transfusi, kadar feritin, dan usia tulang anak pada thalassemia mayor. Sari Pediatr; 2011.13(4):299-304. Available from: https://saripediatri.org/index.php/saripediatri/article/view/428

32. Monastero R, Monastero G, Ciaccio C, Padovani A, Camarda R. Cognitive deficits in beta-thalassemia major. Acta Neurol Scand; 2000.102(3):162-8. DOI: 10.1034/j.1600-0404.2000.102003162.x

33. Lestari LPMD. Pengaruh memori kerja terhadap performa sekolah sebagai salah satu aspek kualitas hidup anak penyandang talasemia beta mayor usia 812 tahun. Universitas Padjadjaran; 2016.

34. Raafat N, El Safy U, Khater N, Hassan T, Hassan B, Siam A, et al. Assessment of cognitive function in children with beta-thalassemia major: a crosssectional study; J Child Neurol. 2015.30(4):417-22. DOI: $10.1177 / 0883073814550827$

35. Schneider ALC, Jonassaint C, Sharrett R, Mosley TH, Astor BC, Selvin E, et al. Hemoglobin, anemia, and cognitive function: The atherosclerosis risk in communities study. Journals Gerontol Med Sci; 2016.71(6):772-9. DOI: 10.1093/gerona/glv158

36. Mackin RS, Insel P, Truran D, Vichinsky EP, Neumayr LD, Armstrong FD, et al. Neuroimaging abnormalities in adults with sickle cell anemia Associations with cognition. Neurology; 2014.82:835-41.

DOI: $10.1212 / W N L .0000000000000188$ 
37. Rehncrona S, Hauge HN, Siesjo BK. Enhancement of iron-catalyzed free radical formation by acidosis in brain homogenates: Difference in effect by lactic acid and CO2. J Cereb Blood Flow Metab; 1989.9(1):65-70. DOI: 10.1038/jcbfm.1989.9

38. Akhlaghpoor S, Ghahari A, Morteza A, Khalilzadeh O, Shakourirad A, Alinaghizadeh MR. Quantitative T2* magnetic resonance imaging for evaluation of iron deposition in the brain of $\beta$-thalassemia patients. Clin Neuroradiol; 2012. 22(3):211-7.

DOI: $10.1007 / \mathrm{s} 00062-011-0108-\mathrm{z}$

39. Lam WWM, Au WY, Chu WCW, Tam S, Ha SY, Pennell DJ. One-stop measurement of iron deposition in the anterior pituitary, liver, and heart in thalassemia patients. J Magn Reson Imaging; 2008. 28(1):29-33. DOI: 10.1002/jmri.21433

40. Nyberg F. The Role of the Somatotrophic Axis in Neuroprotection and Neuroregeneration of the Addictive Brain [Internet]. 1st ed. Vol. 88, International Review of Neurobiology. Elsevier Inc; 2009. 399-427 p. DOI: 10.1016/S00747742(09)88014-8

41. Aberg ND. Role of the Growth Hormone/InsulinLike Growth Factor 1 Axis in Neurogenesis. Pediatr Neuroendocrinol; 2010.17:63-76 DOI:10.1159/000262529

42. Bliss TVP, Cooke SF. Long-term potentiation and long-term depression: a clinical perspective. Clinics; 2011. 66(S1):3-17. DOI: $10.1590 / \mathrm{S} 1807-$ 59322011001300002
43. Nyberg F. Growth hormone in the brain: Characteristics of specific brain targets for the hormone and their functional significance. Front Neuroendocrinol; 2000. 21(4):330-48.

DOI: $10.1006 /$ frne.2000.0200

44. Kenney JW, Gould TJ. Modulation of Hippocampus-Dependent Learning and Synaptic Plasticity by Nicotine. Mol Neurobiol; 2008.38(1):101-21. DOI: 10.1007/s12035-0088037-9

45. Yacobovich J, Tamary H. Thalassemia major and sickle cell disease in adolescents and young adults. Acta Haematol; 2014.132(3-4):340-7.

DOI: $10.1159 / 000360235$

46. Malik S, Syed S, Ahmed N. Complications in transfusion-dependent patients of B-thalassemia major: A review. Pakistan J Med Sci; 2009.25(4):678-82. Available from: https://www.ncbi.nlm.nih.gov/pmc/articles/PMC576 7285/

47. Estrella Castillo DF, Nemegyei JA, de Regil LG. Association between body mass index with cognitive or physical functioning, and depression in Mexican elderly: A cross-sectional study. Neuropsychiatry (London); 2016.6(5):271-9. DOI: $10.4172 /$ Neuropsychiatry.1000149

48. Suemoto CK, Gilsanz P, Mayeda ER, Glymour MM. Body mass index and cognitive function: the potential for reverse causation. Int J Obes (Lond); 2015. Sep;39(9):1383-9. DOI: 10.1038/ijo.2015.83. 